\title{
TALLINN RADIOCARBON DATES III
}

\section{J M PUNNING, T KAKUM, and R RAJAMÄE}

Institute of Geology, Academy of Sciences, Estonian SSR

This list comprises age measurements carried out from 1973 to 1974. In dating the samples reported here as well as in calculating their ages, the same equipment and methods were used as previously described (R, 1973, v 15, p 586-591; 1974, v 16, p 388-394).

Sample ages are calculated using the conventional half-life of $5568 \pm$ $30 \mathrm{yr}$ referred to the standard year 1950.

\section{SAMPLE DESCRIPTIONS}

I. GEOLOGIC SAMPLES

A. Estonian SSR

TIn-106. Viitna

$7630 \pm 70$

$5680 \mathrm{BC}$

Wood peat from bottom of thermokarst hollow near Viitna, Rakvere Dist. Coll 1973 from depth 210 to $215 \mathrm{~cm}$ and subm by R Karukäpp, Inst Geol, Acad Sci Estonian SSR (now Inst Geol). Comment: based on pollen-analytic data, $\mathrm{R}$ Pirrus attributes accumulation of peat to Boreal period.

\section{TIn-111. Mehikoorma}

$4895 \pm 90$

Peat from bottom of Lake Peipsi, ca $2 \mathrm{~km} \mathrm{E}$ of Mehikoorma settlement. Lake depth $11 \mathrm{~m}$ : sample coll from depth 5 to $40 \mathrm{~cm}$ from bottom. Coll 1973 by J M Punning, R Rajamäe, and E Rähni, Inst Geol.

\section{Tln-127. Krüüdneri}

$8330 \pm 110$

Peat from Krüüdneri Bog is in closed ridge of glacial disintegration in Otepää elevation. Sample coll at a lower contact of organic and lake sediments. Coll 1973 and subm by R Karukäpp.

B. North and Northeast of the East European Plain of USSR

\section{TIn-87. Molodyozhnoye}

$6705 \pm 110$

Peat from left bank of Chornaya R, W of town Zelenogorsk, NW part of Leningrad Dist. Sample lies at depth 185 to $190 \mathrm{~cm}$ in organic complex buried under beach barrier of Littorina Sea. Coll 1973 by T Kakum, J M Punning, and R Rajamäe. Comment: sample from depth $205 \mathrm{~cm}$ dated $7350 \pm 70$ (TA-197:R, 1970, v 12, p 245). From pollen-analytic data, L Serebryanny attributes accumulation of organic layers to Pollen Zone
AT 1. 
Tln-100. Molodyozhnoye

$6050 \pm 90$

4100 BC $160 \mathrm{~cm}$.

Sapropel from same complex as Th-87. Sample coll at depth 155 to

$6455 \pm 80$

Tln-88. Tamitsa

4505 BC

Wood remains from marine loam on lower reaches of Tamitsa R, Arkhangelsk Dist. In profile there are 2 complexes of marine deposits (loam and clay) separated by peat. Coll 1973 from upper complex of marine deposits and subm by $\mathrm{B}$ Koshetchkin, Geol Inst, Kola branch Acad Sci USSR.

Tln-89. Tamitsa

$8705 \pm 70$

$6755 \mathrm{BC}$

Peat from isolated complex from profile Tamitsa.

$3935 \pm 60$

Tln-90. Kolvitsa

$1985 \mathrm{BC}$

Wood remains from marine deposits of terrace near mouth of Kolvitsa R, Kola Peninsula. Coll and subm by B Koshetchkin. Comment: plant remains from same complex dated 13,510 \pm 230 , LE-1030. Results of pollen analyses show Atlantic climatic age.

Tln-91. Vonguda

$4030 \pm 90$

2080 BC

Peat from Holocene sediments from bank of Vonguda R, Arkhangelsk Dist. In profile there are 3 complexes of marine deposits separated by lake and bog deposits. Coll 1973 from upper complex and subm by B Koshetchkin.

$7825 \pm 70$

Tln-92. Vonguda

5875 вС

Wood remains from the lower lake and bog deposits in profile Vonguda (see Tln-91).

\section{Tln-112. Sosnovy Bor}

$7840 \pm 60$

5890 BC

Sapropel on left bank of Kowash R, SW part of Leningrad Dist, ca $200 \mathrm{~m}$ from road bridge. Lagoon deposits underneath Littorina Sea deposits are separated from underlying medium-grained sand by peat and lake sediments. Coll 1973 by T Kakum, J M Punning, and R Rajamäe.

Tln-101. Sosnovy Bor

$8270 \pm 120$

$6320 \mathrm{BC}$

Peat from lake and bog deposits on left bank of Kowash R, (see Tln112). Comment: accumulation of peat started after regression of Ancylus Lake. 


\section{Tchimmilitsa series}

Tln-107. Tehimmilitsa

Wood peat from Holocene sec on right bank of Olonka R, Arkhangelsk Dist. Sample depth 325 to $330 \mathrm{~cm}$. Coll 1973 and subm by E Devyatova, Inst Geol, Karelia Branch Acad Sci USSR.

\section{Tln-108. Tehimmilitsa}

$4590 \pm 80$

Wood peat from depth 545 to $555 \mathrm{~cm}$.

\section{Tln-109. Tehimmilitsa}

Reed peat from depth 658 to $665 \mathrm{~cm}$.

\section{Tln-110. Tchimmilitsa}

$6315 \pm 70$

Reed peat from depth 768 to $772 \mathrm{~cm}$.

\section{Tln-113. Virjuga}

4365 BC

Shells from profile on left bank Pjoza $R$ near mouth of Virjuga $R$, Arkhangelsk Dist. Gray sandy loam with shells lie on till. Coll 1973 by $\mathrm{T}$ Kakum, J M Punning, and R Rajamäe. Comment: age dated by outer layer (10 to $50 \%$ ) of shells. According to E Devyatova and E Loseva (1964), sandy loam is deposited by Boreal transgression.

\section{Tln-114. Virjuga}

$40,200 \pm 800$

113. Age is minimum for these deposits.

\section{TIn-115. Kolpino}

$$
3660 \pm 50
$$
of lake $1.6 \mathrm{~m}$, J M Punning, R Rajamäe, and E Rähni. $40 \mathrm{~cm}$ from bottom. Coll 1973 by

\section{Zaton series}

Profile Zaton from left bank of Mezen R, $1.5 \mathrm{~km}$ upstream from Zaton, Arkhangelsk Dist. Dense clay underlies sand complex with shells. Coll 1973 by T Kakum, J M Punning, and R Rajamäe. Outer layer of shells ( 0 to $25 \%$ by weight) was removed.

Tln-120A. 25 to $40 \%$

Tln-120B. 40 to 55\%

Tln-120C. 55 to $70 \%$
$39,500 \pm 900$ 37,550 вс

$24,200 \pm 800$ 22,250 вC

$35,000 \pm 900$ 33,050 BC 
Tln-120D. 85 to $100 \%$

\section{Tln-122. Bolvanski mys}

Peat from cape Bolvanski near Petschora R, Arkhangelsk Dist. Sample coll from sea terrace, at depth $3.2 \mathrm{~m}$. Coll 1969 and subm by $\mathrm{L}$ Rozanov, Inst Geog Acad Sci USSR (now Inst Geog).

\section{Tln-125. Arkhangelsk}

$8370 \pm 100$

\section{$6420 \mathrm{BC}$}

Peat from boring in Arkhangelsk city. Near-shore lake and bog sediments underlain by clay and overlain by sand and peat. Coll 1968 from depth 17.25 to $17.50 \mathrm{~m}$ by $\mathrm{E}$ Garibyan and subm by $\mathrm{O}$ Znamenskaya, Leningrad State Univ.

Tln-126. Arkhangelsk

$9115 \pm 100$

$7165 \mathrm{BC}$

Peat from boring in Arkhangelsk from depth $17.50 \mathrm{~m}$ to $17.70 \mathrm{~m}$.

C. Middle of East European Plain

Tln-121. Tsna

$3330 \pm 60$

1380 BC

Peat with wood remains from flood plain of Tsna R, Moscow Dist. Crescent-lake deposits, $2.5 \mathrm{~m}$ thick, underlain by muddy clay. Coll 1973 from depth $120 \mathrm{~cm}$ and subm by J Glasko, Inst Geog.

TIn-123. Glazov

$1790 \pm 70$

AD 160

Wood remains from 1st riparian terrace, Tchentsa $\mathrm{R}, 13 \mathrm{~km}$ upstream from Glazov, Udmurt ASSR. Tree trunk is embedded in crescent-lake sediments at depth 3.9 to $4.15 \mathrm{~m}$. Coll 1973 and subm by L Rozanov.

Tln-124. Moksha

$2575 \pm 60$

$625 \mathrm{BC}$

Wood remains from lst terrace of Moksha $\mathrm{R} 6 \mathrm{~km} \mathrm{~S}$ from Kadoma. Tree trunk is embedded in crescent-lake sediments at depth $3.6 \mathrm{~m}$. Coll 1973 and subm by J Glasko.

\section{Far East and East Siberia}

\section{Tln-102. Reineke}

$3375 \pm 110$

$1425 \mathrm{BC}$

Shells from the coast of Ohhota Sea at Reineke sound. Coll 1971 from submerged beach at beach barrier and subm by J Veinbergs, AllUnion Research Inst Marine Geol.

\section{Tln-103. Urkt}

Well-decomposed peat from cliff in Urkt sound of NE Sahalin I; alurite with organogenic deposits lie at depth 3 to $3.4 \mathrm{~m}$. Coll 1971 and subm by J Veinbergs. 


\section{TIn-105. Routan}

Peat from sec on NE coast of Bolshoi Routan, Siberian Sea. Well decomposed peat underlie silty sand. Coll 1973 and subm by J Veinbergs.

\section{E. Middle Asia of USSR}

\section{Tln-104. Kulanda}

$$
2860 \pm 80
$$

Shells from coastal deposits $7 \mathrm{~km} \mathrm{~S}$ from Kulanda, on N coast of Aral Sea. Coarse-grained sands with shells lay at depth .5 to $1.5 \mathrm{~m}$. Coll 1969 and subm by J Veinbergs.

\section{Tln-116. Kokand}

$$
1390 \pm 65
$$

Peat from alluvial bog deposits from lst riparian terrace, Naimansay R, near Kokand, Fergana valley. Coll 1972 from depth $.3 \mathrm{~m}$ by $\mathrm{L}$ Serebryanny, T Serebryannaya, and G Pshenin, Inst Geog.

\section{ARCHAEOLOGIC SAMPLES}

\section{Estonian SSR}

\section{Tln-93. Arniko}

$$
1395 \pm 80
$$

Charcoal from burial mound near Arniko, Põlva Dist. Depth of sample $.2 \mathrm{~m}$. Archaeologic analysis shows 4th to 5th centuries. Coll 1973 and subm by M Aun, Inst Hist Acad Sci, Estonian SSR (now Inst Hist).

Tln-94. Arniko

$$
1455 \pm 70
$$

Charcoal from burial mound near Arniko. Coll 1973 from depth $.3 \mathrm{~m}$ and subm by M Aun.

\section{TIn-95. Kivivare}

$$
1315 \pm 100
$$

Charcoal from ancient settlement Kivivare, Valga Dist. Estimated archaeologic age 8th to 10th centuries. Coll 1972 from depth 85 to $90 \mathrm{~cm}$ and subm by M Aun.

\section{TIn-96. Kivivare}

$$
\mathbf{3 4 0} \pm \mathbf{8 0}
$$

Charcoal from ancient settlement Kivivare. Coll 1972 from depth $70 \mathrm{~cm}$, and subm by M Aun.

\section{TIn-97. Kivivare}

$$
1570 \pm 70
$$

Charcoal from ancient settlement Kivivare. Coll 1972 from depth $100 \mathrm{~cm}$ and subm by M Aun. 
Tln-98. Polgaste

$1105 \pm 110$

AD 845

Charcoal from burial mound near Põlgaste, Põlva Dist. Estimated archaeologic age: 1st century. Coll 1973 from depth 85 to $100 \mathrm{~cm}$ and subm by S Laul, Inst Hist.

\section{Tln-99. Polgaste}

$1725 \pm 60$

Charcoal from burial mound near Põlgaste. Coll 1973 from depth $120 \mathrm{~cm}$ and subm by $S$ Laul.

\section{REFERENCES}

Devyatova, E and Loseva, E, 1964, Stratigrafiya i paleogeografiya tschetvertitschnovo periyoda $\mathbf{v}$ basseine reki Mezeni: Nauka, Leningrad.

Ilves, E, Punning, J M, and Liiva, A, 1970, Tartu radiocarbon dates IV: Radiocarbon, v 12, p 238-248.

Punning, J M, Kakum, T, and Rajamäe, R, 1973, Tallinn radiocarbon dates I: Radiocarbon, $v 15, \mathrm{p} 586-581$.

1974, Tallinn radiocarbon dates II: Radiocarbon, v 16, p 388-394. 